\title{
MENINGKATKAN KEMAMPUAN MOTORIK KASAR MELALUI PERMAINAN TRADISIONAL "SIKODOKA" BAGI ANAK USIA DINI BERLATAR BELAKANG TUNA GRAHITA
}

\author{
Mientje Ratoe Oedjoe \& Beatriks Novianti Bunga \\ e-mail:boenga.eve@gmail.com \\ Fakultas Keguruan dan IImu Pendidikan Universitas Nusa Cendana \\ JI. Adisucipto Penfui, Nusa Tenggara Timur
}

\begin{abstract}
Abstrak: Perkembangan fisik pada sebagian anak tunagrahita mengalami keterhambatan. Keterhambatan fisik ini mengakibatkan masalah pada keterampilan geraknya. Karenanya membutuhkan praktik-praktik yang dapat mengembangkan kemampuan fisik motorik kasar anak usia dini tunagrahita. Metode penelitian menggunakan penelitian tindakan kelas yang dilalui dalam dua siklus dengan empat kali pertemuan. Penelitian ini dilaksanakan pada bulan Agustus 2016 di SLBN Kelapa Lima Kota Kupang. Partisipan penelitian sebanyak tiga orang yang berusia dini yaitu tujuh sampai dengan sembilan tahun. Teknik pengumpulan data menggunakan observasi serta tes. Indikator peningkatan kemampuan fisik motorik dilihat berdasarkan kemampuan melompat satu kaki, melompat dua kaki, menjaga keseimbangan tubuh saat memungut "era", melempar "era" tepat dalam kotak, serta kemampuan menggenggam "era" dengan baik. Hasil penelitian menunjukkan bahwa terjadi peningkatan kemampuan fisik motorik kasar anak usia tuna grahita dengan peningkatan rerata dari pra siklus 38\% meningkat $23 \%$ menjadi $61 \%$ di siklus 1 . Dari siklus I ke siklus 2 meningkat lagi 43\% sehingga kondisi setelah pelaksanaan siklus 2 adalah $95 \%$. Berdasarkan hasil evaluasi maka direkomendasikan kepada guru agar peka terhadap kondisi anak yang mudah terbagi konsentrasi, menggunakan sistem hadiah untuk menarik perhatian anak, harus lebih sering memuji, membuat variasi tepukan untuk mengembalikan konsentrasi anak, mengurangi aktivitas-aktivitas yang memicu perilaku ramai muncul, menggunakan bahasa yang sederhana, pemenggalan kalimat yang jelas dan tidak panjang, mengulang-ulang permainan karena anak tunagrahita mudah lupa.
\end{abstract}

Kata Kunci: tunagrahita, permainan tradisional Sikodoka, motorik kasar, anak usia dini

\section{IMPROVING GROSS MOTOR SKILLS THROUGH TRADITIONAL GAME "SIKODOKA" IN EARLY CHILDHOOD WITH INTELLECTUAL DISABILITY}

\begin{abstract}
Physical development in some children with intellectual disability could be delayed. This physical delays can trouble their movement skills. Therefore these children need practices that could improve their gross motoric skills. This research aimed to try out Sikodoka game in order to improve gross motor skills in young children with intellectual disability. Method used was class action research conducted in two cycles and four meetings. Research participants were three young children aged seven to nine years old. The research was conducted in August 2016 taking palce in Kelapa Lima Special Needs School, Kupang. Data collection techniques used were observation and test. Gross motor skills indicators were jumping with one foot skill, jumping with both feet, keeping body balance while collecting "era", tossing "era" correctly inside the square, and grasping "era" skillfully. Results showed that there was improvement in gross motor skills with mean improvement from pre-cycle $38 \%$ increased $23 \%$ to $61 \%$ in cycle 1 . From cycle 1 to cycle 2 improved again 43\% making the condition after cycle 2 was 95\%. According to the evaluation, recommendations to teachers are to be sensitive to children's condition that are easy to be divided in their focus, using reward system to attract children's attention, need to compliment more, uses clapping variations to recover children's focus, reducing activities that could trigger loud activities, using simple languages, dividing sentences that are clear and not long, and reprating games because children with intellectual disability are easy to forget.
\end{abstract}

Keywords: intellectual disability, Sikodoka traditional game, gross motor, young children 


\section{PENDAHULUAN}

Perkembangan fisik pada sebagian anak tunagrahita mengalami keterhambatan. Keterhambatan fisik ini mengakibatkan masalah pada keterampilan geraknya (Utari \& Indahwati, 2015). Menurut Delphie (2007), anak tunagrahita pada umumnya mempunyai kelemahan pada segi keterampilan gerak, fisik yang kurang sehat, koordinasi gerak, kurangnya perasaan dirinya terhadap situasi dan keadaan sekelilingnya, dan kurang keterampilan gross motor (motorik kasar) dan fine motor (motorik halus). Anak usia dini tunagrahita ringan mengalami kesulitan dalam melakukan aktivitas jasmani/gerak dasar seperti berlari, melompat, meloncat dan juga kurang dapat atau masih kesulitan melakukan gerakan manipulasi sebuah benda (melempar, menangkap). Mereka dapat mengikuti aktivitas bermain tetapi dengan arahan yang sederhana (Auxter, Pyfer, Huettig, dalam Ardiyanto \& Sukoco, 2014). Karenanya membutuhkan praktik-praktik yang dapat mengembangkan kemampuan fisik motorik. Bermain merupakan salah satu cara yang ideal terkait praktik tersebut.

Bermain, sama halnya dengan belajar, adalah hidup dan pekerjaan anak (Samuelsson \& Clarsson, 2008). Terlepas apakah anak tersebut bermasalah atau tidak, normal ataupun kebutuhan khusus. Bermain memiliki fungsi sebagai jendela ke dalam jiwa anak dan merupakan aktivitas favorit anak dan dianggap sebagai kendaraan terbaik untuk memfasilitasi perkembangan anak. Bermain sebagai tempat ekspresi diri, komunikasi, perkembangan hubungan dengan orang lain dan perkembangan kapasitas diri baik untuk anak pada umumnya maupun pada anak berkebutuhan khusus (Luby, 2006). Kajian Odom dan Wolery (2003) menyebutkan bahwa anak usia dini dengan disabilitas termasuk tunagrahita akan belajar banyak melalui bermain dan mengobservasi lingkungan mereka.

Sudah banyak penelitian-penelitian yang menjelaskan mengenai manfaat media permainan dalam proses pembelajaran bagi anak berkebutuhan khusus tunagrahita. Penelitian yang dilakukan oleh Sekarwati dan Riyanto (2015) yakni penelitian tindakan kelas (PTK) untuk melihat kemampuan motorik halus anak tunagrahita dan apakah dapat berkembang ketika anak diberi permainan maze matching sebagai tindakannya. Hasil peneltian menunjukkan bahwa ada perubahan anak ketika menggenggam, memindahkan barang, menjumput benda dengan jarinya. Penelitian lain berjudul media pembelajaran interaktif keterampilan membatik untuk anak tunagrahita ringan pada sekolah luar biasa di semarang yang dilakukan oleh Fitriana (2013). Hasil penelitian memperlihatkan membatik adalah media yang menyenangkan dan mudah serta dapat diterapkan sebagai media pembelajaran bagi anak tunagrahita dan juga dapat mengembangkan kemampuan fisik motorik anak tunagrahita.

Salah satu permainan yang perlu dieksplorasi adalah permainan tradisional. Permainan tradisional juga merupakan media yang tidak kalah fungsinya dengan permainan edukatif lainnya. Ardiyanto dan Sukoco (2014) dalam penelitiannya menggunakan delapan permainan tradisional sebagai model yang dikembangkan yaitu permainan, yaitu (1) balap sarung, (2) lempar karet, (3) dorong ban, (4) engkling, (5) pukul balon, (6) layang-layang, (7) lompat tali, dan (8) pesawat terbang. Delapan permainan ini telah diujicoba dan dianggap layak untuk diijadikan model pengembangan motorik kasar bagi anak tunagrahita. Uji coba skala kecil model dilakukan di Sekolah Luar Biasa (SLB) Tunas Kasih Turi dan uji coba skala besar di SLB Tunas Kasih Donoharjo.

Permainan engklek (Asih, 2014) dilakukan untuk melihat bagaimana manfaatnya bagi perkembangan motorik kasar anak tunagrahita. Hasil menunjukkan bahwa permainan engklek dapat bermanfaat bagi perkembangan melompat anak tunagrahita. Penelitian terbaru tahun 2015 mengenai engklek dilakukan oleh Sari (2015) tentang peningkatan kemampuan pengenalan bilangan bagi anak tunagrahita sedang di SLB Payahkumbuh, kelas DIII menemukan bahwa ketika kotak-kotak dalam engklek tersebut diberi angka, maka terjadi peningkatan pengenalan angka bagi anak tunagrahita sedang. Penelitian lain dari Alfiza dkk. (2014) membahas permainan lompat tali dan mencoba melakukan PTK untuk mencari tahu apakah ada peningkatan kemampuan motorik kasar anak tuna grahita dalam hal ini melompat bagi anak kelas II (umur 11 tahun) dengan tunagrahita ringan di Painan. Hasilnya menunjukkan bahwa dengan bermain lompat tali dapat melatih kemampuan melompat anak tuna grahita menjadi lebih baik. 
Penelitian-penelitian yang dipaparkan di atas menunjukkan bahwa bermain memiliki peran yang penting dalam mengembangkan kemampuan anak tunagrahita, termasuk di dalammnya adalah permainan tradisional. Permainan-permainan ini juga memberi kontribusi besar terutama pengembangan motorik kasar anak usia dini tunagrahita. Sayangnya karena beberapa keterbatasan, penggunaan media bermain ini sering terlupakan, apalagi dalam pembelajaran bagi anak usia dini dengan kebutuhan khusus tunagrahita.

Hasil penelitian Ratoe Oedjoe \& Bunga (2015) menemukan minimnya penggunaan media pembelajaran di SLB di Kota Kupang. Mereka cenderung menerapkan pendekatan secara individual yang menekankan kepada pendampingan secara personal untuk meningkatkan kemampuan anak usia dini tunagrahita. Penggunaan media dalam proses pembelajaran pun kurang variatif hanya media klasik seperti kartu angka dan kartu huruf. Jika ada media dari alam, itu terbatas untuk membantu guru di dalam kelas. Media itu seperti batu, kelereng, daun, dan lidi. Pemanfaatan permainan kurang dilaksanakan walaupun secara teoretis paham akan pentingnya bermain yang bervariasi bagi pengembangan kemampuan anak, terutama anak tunagrahita. Anak-anak cenderung dibiarkan bermain sendiri tanpa pengawasan dan itu hanya dilakukan saat istirahat. Permainan anak sendiri pun hanya berupa bermain kejar-kejaran di lapangan sekolah. Tidak ada permainan tradisional yang dipakai dalam pembelajaran.

Sebenarnya ada banyak jenis permainan tradisional yang ada di Kupang atau Nusa Tenggara Timur secara umum. Permainan Sikodoka adalah salah satunya. Sikodoka (dalam bahasa Jawa engklek) adalah permainan tradisional yang cara bermainnya dengan melompati kotak-kotak yang digambar di tanah. Ada tiga jenis Sikodoka yang sering dimainkan anak, yaitu Sikodoka kotak, Sikodoka salib dan Sikodoka dua kaki. Permainan ini menggunakan alat bantu batu ceper yang disebut "era". Anak harus memilih era yang tepat, yang ceper dan bulat dan tidak licin karena era akan dibuang ke dalam kotak-kotak. Kemudian anak harus melompati semua kotak-kotak tersebut dan kemudian mengambil era yang dibuang tadi. Permainan dilakukan paling sedikit dua orang.

Permainan ini memiliki banyak manfaat. Mulai dari pemilihan era saja sudah mengajar anak untuk mengenal perbedaan bentuk batu, menggambar kotak-kotak, dan melompat. Berdasarkan hasil riset, permainan ini teruji mampu meningkatkan kemampuan akademis di bidang matematika -pengenalan angka dan motorik kasar- yaitu melompat. Permainan ini dapat dimodifikasi lebih sederhana agar sesuai dengan karakteristik perkembangan anak tunagrahita ringan seperti kotak-kotaknya akan ditulisi angka 1-10, kotakkotaknya dibatasi jumlahnya paling banyak 10 dapat pula lebih sedikit, dan aturannya dapat dibuat lebih sederhana seperti apabila jatuh, harus berganti dengan lawan. Agar anak tunagrahita senang dan belajar, guru dapat memberinya penguatan berupa pujian ataupun sepotong kue.

Permainan Sikodoka sangat sederhana dimainkan. Untuk bisa bermain, setiap anak harus menyiapkan "era". Era ini bisa berupa batu ceper, pecahan keramik atau genteng. Anak cukup melompat menggunakan satu kaki di setiap kotakkotak yang telah digambarkan sebelumnya di tanah. Era dilempar ke salah satu kotak yang tergambar di tanah, kotak yang ada eranya tidak boleh diinjak/ ditempati oleh setiap pemain, jadi para pemain harus melompat ke kotak berikutnya dengan satu kaki mengelilingi kotak-kotak yang ada. Saat melemparkannya tidak boleh melebihi kotak yang telah disediakan jika melebihi maka dinyatakan gugur dan diganti dengan pemain selanjutnya. Pemain yang menyelesaikan satu putaran terlebih dahulu melemparkan era dengan cara membelakangi engkleknya, jika pas pada petak yang dikehendaki maka petak itu akan menjadi "rumah"nya, artinya dikotak tersebut pemain yang bersangkutan dapat menginjak kotak tersebut dengan dua kaki, sementara pemain lain tidak boleh menginjak kotak itu selama permainan. Peserta yang memiliki "rumah" paling banyak adalah pemenangnya.

Pemainan ini sangat seru karena biasanya paling sering kesalahan yang dilakukan adalah saat melempar era tapi tidak pas dikotaknya atau meleset dari tempatnya. Manfaat yang diperoleh dari permainan Sikodoka ini antara lain (a) kemampuan fisik anak menjadi kuat karena dalam permainan engklek ini anak diharuskan untuk melompat-lompat, (b) mengasah kemampuan bersosialisasi dengan orang lain dan mengajarkan kebersamaan, dan (c) dapat mentaati aturan-aturan permainan yang telah.

Berdasar latar belakang tersebut maka peneliti melakukan perbaikan pembelajaran dengan 
menggunakan tindakan permainan tradisional untuk memperbaiki pembelajaran anak usia dini tunagrahita di SLB. Tindakan permainan tradisional yang akan diberi adalah permainan Sikodoka. Permainan tradisional Sikodoka diharapkan mampu membantu meningkatkan kemampuan fisik anak terutama motorik kasar. Penelitian ini diharapkan mampu mendorong guru untuk menerapkan praktikpraktik yang teruji secara ilmiah untuk membantu perkembangan anak didiknya.

\section{METODE PENELITIAN}

Penelitian ini menggunakan jenis penelitian kuantitatif dengan pendekatan Penelitian Tindakan Kelas. Kelas yang menjadi sasaran penelitian adalah kelas 1 Sekolah Dasar karena tidak ada kelas PAUD untuk anak berkebutuhan khusus. Selain itu juga kelas 1 SD terdapat murid yang masih dikategorikan usia dini yaitu 7-9 tahun. Partisipan penelitian adalah anak kelas $1 \mathrm{SD}$ berjumlah tiga orang, dua orang perempuan (E berumur 9 tahun, W berumur 6 tahun) dan 1 orang laki-laki ( $R$ berusia 8 tahun). Tempat penelitian dilakukan di SLBN Kelapa Lima Kota Kupang. Penelitian ini dilaksanakan pada bulan Agustus 2016.

Teknik pengumpulan data menggunakan observasi dan tes. Observasi dilakukan terhadap proses pembelajaran, juga perilaku yang muncul saat pembelajaran sedangkan tes dilakukan di akhir setiap siklus. Instrumen penilaian tes adalah kemampuan fisik motorik kasarnya, yaitu melompat dua kaki, melompat menggunakan 1 kaki, melempar "era" masuk dalam kotak sambil menjaga keseimbangan tubuh dan kemampuan menggenggam "era".

Penelitian ini dilalui dalam dua siklus dengan jumlah pertemuan sebanyak empat pertemuan. Siklus pertama, hari pertama dilakukan permainan dan hari kedua dilakukan tes. Begitu juga dengan siklus dua. Setiap siklus dilalui dalam empat tahapan yaitu: (1) persiapan: menyiapkan $\mathrm{RPPH}$, diskusi dengan guru, menyiapkan alat dan bahan bermain Sikodoka; (2) pelaksanaan: guru menerapkan tahapan bermain Sikodoka; (3) observasi: observasi dilakukan terhadap pelaksanaan kegiatan, perilaku yang muncul saat bermain serta observasi terhadap peningkatan kemampuan motorik halus. Penilaian terhadap kemampuan ini dilakukan melalui tes; dan (4) refleksi: refleksi ini dilakukan untuk memberikan motivasi untuk terus bersemangat mengikuti pembelajaran yang menyenangkan.

\section{HASIL DAN PEMBAHASAN}

\section{Deskripsi Pra Siklus}

Proses pengambilan data penelitian dimulai dengan proses pra siklus. Pada pra siklus ini akan dilihat sejauh mana kemampuan fisik motorik kasar anak usia dini tunagrahita. Dalam pra siklus ini peneliti melakukan simulasi motorik kasar dengan bermain gerak dan lagu "Jalan-jalan". Dalam lagu ini, anak harus melakukan aktivitas motorik seperti berjalan, melompat satu kaki, melompat dua kaki, gerakan melempar, menggenggam, dan keseimbangan tubuh. Simulasi ini dilakukan agar peneliti mendapat gambaran mengenai kondisi fisik motorik anak.

Berdasarkan hasil simulasi diperoleh tingkat kemampuan fisik motorik anak usia dini tunagrahita masih rendah dengan nilai rerata kemampuan anak sebesar 0,38 (38\%). Untuk aktivitas mengajar dan pemanfaatan metode, didasarkan kepada hasil penelitian terdahulu peneliti bahwa pemanfaatan media dalam pembelajaran sangat minim termasuk pemanfaatan permainan tradisional. Simulasi ini dilakukan oleh guru kelas dan peneliti hanya mengobservasi. Untuk lebih jelasnya, hasil tes pra siklus tersaji pada tabel 1.

Tabel 1. Hasil Tes Pra Siklus

\begin{tabular}{ccccccc}
\hline & A & B & C & D & E & Total \\
\hline $\mathrm{E}$ & 2 & 1 & 1 & 1 & 2 & 7 \\
$\mathrm{R}$ & 3 & 1 & 2 & 1 & 3 & 10 \\
$\mathrm{~W}$ & 1 & 1 & 1 & 1 & 2 & 6 \\
\hline \multicolumn{7}{c}{ Jumlah Total } \\
\hline \multicolumn{7}{c}{ Rerata } \\
\hline
\end{tabular}

\section{Siklus I}

Pada pertemuan pertama, guru kelas memperkenalkan tim peneliti kepada anak-anak lalu mengabsen dan mengajak untuk berdoa. Selanjutnya, guru menyerahkan sepenuhnya pembelajaran kepada tim. Guru bertindak sebagai observer untuk melihat keberlangsungan proses. Kemudian dilakukan perkenalan bersama anakanak. Untuk perkenalan, guru melakukan pendekatan dengan gerak dan lagu. Gerak dan lagu "jalan-jalan" 
diulang kembali dan lagu "kalau kau suka hati". Gerak dan lagu ini dilakukan untuk mencairkan suasana karena pada pertemuan pertama, anak masih menunjukkan perilaku malu-malu dan diam pasif, enggan mengikuti perintah serta gerak dari lagu yang dinyanyikan. Ini dikarenakan, anak baru pertama kali bertemu dengan tim peneliti.

Setelah terlihat perilaku aktif, maka peneliti melanjutkan ke kegiatan inti yaitu perkenalan permainan Sikodoka kepada anak. Dimulai dengan membuat pola yang sudah disiapkan di atas karpet dan menjelaskan tentang aturan lalu memberi contoh bagaimana memainkannya. Kemudian, mengajak anak untuk melakukan aktivitas seperti melompat. Pada aktivitas inti juga anak masih terlihat pasif dan mudah berganti konsentrasi, mereka tertarik dengan hal lain di dalam kelas, menolak bermain, serta berlari-lari dalam kelas. Guru sendiri mengalami kesulitan dalam mengajak anak untuk memainkan permainan Sikodoka. Hal ini disebabkan karena beberapa hal yaitu anak masih belum kenal dan akrab dengan tim, bahasa yang digunakan tim untuk menerangkan tahapan bermain masih kompleks dan sulit dipahami anak, peneliti masih bingung mengatasi perilaku anak yang mudah berganti fokus. Untuk memotivasi anak agar terlibat dan menikmati pembelajaran, peneliti mengajarkan tepukan motivasi yaitu Tepuk Bisa. Setelah ketiga anak berhasil mencontoh permainan Sikodoka, peneliti mengakhirinya dengan Tepuk Hore dan pemberian bros bintang lalu di akhiri dengan berdoa. Berdasarkan hasil catatan pengamat ada beberapa catatan perbaikan untuk pertemuan kedua yaitu guru harus membagi perhatian kepada semua anak, harus memuji sesering mungkin, serta menggunakan bahasa yang sederhana dan singkat.

Pertemuan kedua dilakukan pada keesokan harinya. Guru langsung menyerahkan proses pembelajaran kepada tim peneliti. Hari kedua dimulai dengan doa dan menyanyi untuk mencairkan suasana. Lalu tim melakukan sedikit tanya jawab untuk mengetahui apakah mereka mengingat aktivitas pada pertemuan pertama. Anak yang berani menjawab akan diberi bros bintang. Anak terlihat bingung saat dilakukan tanya jawab. Peneliti harus memberi contoh dan menunjukkan gambar sebagai kisi-kisi aktivitas pada pertemuan pertama. Anak mampu mengingat kembali walaupun tidak tepat. Setelah tanya jawab, anak diajak bermain Sikodoka. Tetapi kali ini anak harus memainkan sendiri. Siapa yang berhasil melompat mengelilingi kotak-kotak seperti yang dicontohkan, akan diberi sebuah bintang. Setiap anak diberi kesempatan dua kali bermain.

Berdasarkan hasil catatan observasi terhadap proses pembelajaran, perilaku malu-malu anak berkurang, justru anak semakin ramai, berteriakberteriak, melompat-lompat kegirangan, masih berlari-lari jika bukan giliran bermainnya, dan mudah berganti fokus. Peneliti sendiri menyederhanakan bahasa yang dipakai dan juga lebih sering memuji anak, lebih banyak menggunakan variasi tepukan untuk mengembalikan fokus anak. Di akhir sesi dilakukan tes untuk melihat apakah ada peningkatan kemampuan anak dalam hal melompat satu kaki, melompat dua kaki, serta menjaga keseimbangan tubuh saat memungut, melempar dan menggenggam. Berdasarkan hasil tes diperoleh diperoleh rerata kemampuan fisik motorik anak usia dini tunagrahita sebesar 0.61 atau $61 \%$. Angka ini belum memenuhi kriteria ketuntasan pembelajaran. Untuk itu pelaksanaan siklus dilanjutkan ke siklus kedua.

Berdasarkan hasil catatan observasi maka dilakukan perbaikan pembelajaran melompat satu kaki, menjaga keseimbangan tubuh dan melempar karena ketiga indikator ini yang tidak mengalami banyak peningkatan. Perbaikan lain adalah menyempurnakan RPP berdasarkan masukan pada pelaksanaan siklus I, mempersiapkan hadiah, kali ini diganti berupa makanan biskuit gandum, dan memindahkan permainan keluar kelas yang sepi. Untuk lebih jelasnya, hasil tes siklus 1 tersaji pada tabel 2.

Tabel 2. Hasil Tes Siklus I

\begin{tabular}{ccccccc}
\hline & A & B & C & D & E & Total \\
\hline $\mathrm{E}$ & 3 & 3 & 2 & 3 & 3 & 14 \\
$\mathrm{R}$ & 3 & 3 & 2 & 2 & 3 & 13 \\
$\mathrm{~W}$ & 2 & 2 & 2 & 2 & 2 & 10 \\
\hline \multicolumn{7}{c}{ Jumlah Total } \\
\hline \multicolumn{7}{c}{ Rerata } \\
\hline
\end{tabular}

\section{Siklus II}

Siklus II dilakukan seminggu setelah siklus I dengan jumlah pertemuan sebanyak dua kali. Pada siklus II akan difokuskan pada latihan keseimbangan dan melempar. Permainan dilakukan di luar kelas di sebuah lapangan yang tidak banyak dilalui anak- 
anak lain. Pada pertemuan pertama, kegiatan dimulai dengan doa dan mencairkan suasana dengan menyanyi. Awalnya anak masih malumalu, tetapi setelah menyanyi, anak mulai akrab kembali dengan tim peneliti. Kegiatan inti dimulai dengan penjelasan aturan bermain yaitu siapa yang mampu menyelesaikan satu putaran permainan tanpa diulang akan diberi hadiah berupa biskuit gandum dan siapa yang paling banyak mendapatkan "rumah" adalah pemenangnya. Kemudian anakanak kembali diperkenalkan alat bermain berupa era dan bentuk Sikodoka juga cara bermain. Hal ini dilakukan agar anak usia dini tunagrahita mengingat kembali permainan Sikodoka. Setelah itu, permainan dilakukan. Saat bermain, anak tampak kegirangan senang dan beberapa kali melompat-lompat dan juga berlari-lari. Anak kelihatan sudah mengetahui permainan Sikodoka tetapi masih belum memahami aturan bermain. Siklus diakhiri dengan pemberian hadiah biskuit bagi yang berhasil dan doa selesai.

Berdasarkan hasil catatan observasi proses kegiatan, terdapat beberapa hal untuk diperbaiki pada pertemuan kedua yaitu mengurangi kegiatankegiatan yang menstimulus perilaku senang berlebihan seperti variasi tepukan "hore" atau memberi motivasi dengan tepuk tangan karena anak terpicu untuk kegirangan berlebihan dengan tepuk tangan yang ramai.

Pertemuan kedua diawali dengan doa dan dilakukan tes. Tes ini untuk melihat peningkatan kemampuan fisik motorik kasar anak usia dini tunagrahita setelah dilakukan siklus II. Tes yang dilakukan berupa tes kemampuan melompat satu kaki, melompat dua kaki, melempar, menggenggam, dan menjaga keseimbangan tubuh. Hasil tes menunjukkan rerata nilai tes pada siklus dua 0.95 atau $95 \%$. Ini berarti ada terjadi peningkatan sebesar 0.34 atau $34 \%$ dari siklus I. Untuk lebih jelasnya, hasil tes siklus 1 tersaji pada tabel 3 .

Tabel 2. Hasil Tes Siklus II

\begin{tabular}{ccccccc}
\hline & A & B & C & D & E & Total \\
\hline E & 4 & 3 & 3 & 3 & 4 & 17 \\
$\mathrm{R}$ & 4 & 3 & 3 & 2 & 4 & 16 \\
W & 3 & 3 & 2 & 2 & 4 & 14 \\
\hline \multicolumn{7}{c}{ Jumlah Total } \\
\hline \multicolumn{7}{c}{ Rerata } \\
\hline
\end{tabular}

Berdasarkan hasil pelaksanaan siklus maka dapat dilihat dinamika peningkatan kemampuan fisik motorik kasar anak usia dini dengan tunagrahita ringan disajikan pada Gambar 1.

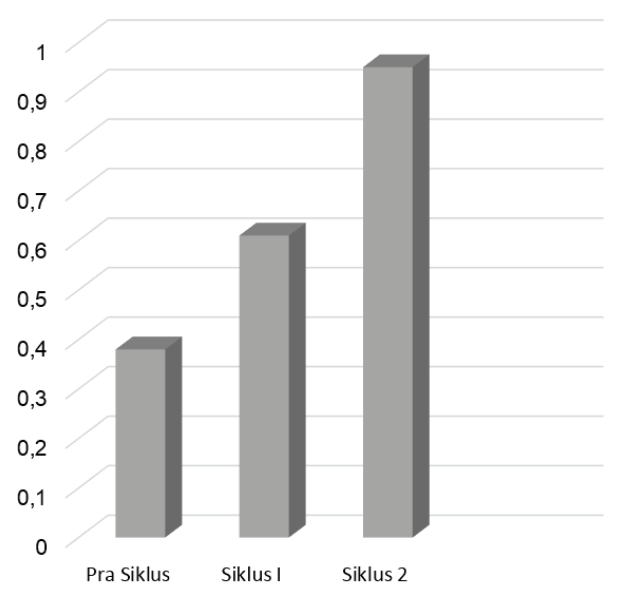

Gambar 1. Grafik peningkatan kemampuan motorik kasar AUD dengan tunagrahita ringan

Hasil penilaian terhadap fisik motorik kasar anak tunagrahita dilihat dari beberapa lima indikator yaitu kemampuan melompat dua kaki, kemampuan melompat satu kaki, kemampuan menjaga keseimbangan, kemampuan melempar, dan kemampuan menggenggam. Hasil simulasi yang dilakukan pada pra siklus untuk melihat kemampuan awal anak usia dini tunagrahita menunjukkan tingkat kemampuan fisik motorik kasar anak masih rendah, dengan rerata nilai 0.38 . Dengan pelaksanaan tindakan permainan tradisional Sikidoka maka terjadi peningkatan rerata menjadi 0.61 . Karena belum mencapai $75 \%$ maka berdasarkan hasil evaluasi maka tindakan diulangi lagi pada siklus II. Terjadi peningkatan kemampuan setelah pelaksanaan tindakan diulangi lagi pada siklus II. Rerata capaian kemampuan fisik motorik kasar anak meningkat menjadi 0.95. Angka ini menunjukkan bahwa kemampuan ketiga anak usia dini tunagrahita sudah memenuhi standar kompetensi yang diharapkan yaitu $75 \%$. Artinya, juga bahwa kemampuan melompat dengan dua kaki, kemampuan dengan menggunakan satu kaki, kemampuan menjaga keseimbangan, kemampuan melempar dan menggenggam anak sudah sesuai tahapan perkembangan. Peningkatan kemampuan fisik motorik kasar anak ini dapat dicapai karena pelaksanaan tindakan permainan tradisional Sikidoka yang dimainkan sesuai kondisi kebutuhan khusus anak, seperti aturan main yang disederhanakan, perintah pelaksanaan permainan 
yang singkat dan jelas, serta pemberian motivasi seperti pujian terus menerus, durasi waktu bermain yang tidak panjang,

Hasil penelitian di atas mempertegas hasilhasil penelitian sebelumnya. Penelitian serupa tentang pemanfaatan permainan tradisional untuk meningkatkan kemampuan lokomotor anak tunagrahita. Kemampuan gerak lokomotor anak tunagrahita meningkat secara signifikan setelah diberi permainan tradisional memindahkan barang dan engkleng gunung (Utari \& Nanik, 2015). Permainan sikidoka ternyata juga mempengaruhi perkembangan lain selain perkembangan motorik maupun gerak lokomotor anak usia dini tuna grahita. Penelitian Sari (2015) menunjukkan peningkatan kemampuan mengenal bilangan yang signifikan pada anak tunagrahita ketika menggunakan permainan engklek atau sikodoka ini. Permainan ini dimodifikasi dengan memberi angka di tiap kotak yang ada. Dari hasil-hasil penelitian di atas dan hasil penelitian ini terungkap juga bahwa peningkatan kemampuan anak tunagrahita dapat terjadi dikarenakan beberapa hal yaitu penyederhanaan permainan tradisional yang ingin dimainkan, penggunaan bahasa sederhana dan singkat, mengulang-ngulang permainan beberapa kali dan selalu memberi motivasi pada saat anak malu-malu dan tak mampu, serta memberi reward saat anak berhasil.

Selain memperkuat hasil penelitian sebelumnya, penelitian ini memberikan eviden baru mengenai penerapan permainan tradisional untuk meningkatkan kemampuan motorik kasar anak usia dini tunagrahita. Kebutuhan perkembangan anak usia dini yang berbeda dengan anak yang lebih tua diharapkan dapat difasilitasi dengan permainan tradisional Sikodoka seperti sudah dibuktikan di penelitian ini. Langkah selanjutnya adalah mentransfer pengetahuan ini untuk diterapkan di kegiatan sekolah maupun di rumah untuk memaksimalkan aplikasi ilmu.

\section{PENUTUP}

\section{Kesimpulan}

Dari hasil penelitian dapat disimpulkan bahwa permainan tradisional Sikodoka efektif dalam meningkatkan kemampuan motorik kasar anak usia dini tunagrahita. Eviden baru dalam konteks anak usia dini tunagrahita ini bisa bermanfaat untuk kegiatan sekolah maupun di rumah demi menunjang perkembangan anak. Eviden ini juga seharusnya bisa meyakinkan para praktisi perkembangan dan pendidikan anak untuk beralih dari metode-metode konvensional dalam belajar dan memanfaatkan permainan tradisional untuk anak usia dini. Diseminasi hasil lebih lanjut serta sosialisasi dibutuhkan untuk mewujudkan hal tersebut.

\section{Saran}

Adapun beberapa hal yang direkomendasikan antara lain adalah bagi guru merencanakan permainan tradisional sebagai media dalam pembelajaran anak tunagrahita apalagi anak usia dini. Selain itu orangtua juga perlu mempertimbangkan untuk mendorong anak bermain tradisional di kehidupan bermain sehari-hari anak. Permainan Sikodoka dapat menjadi salah satu alternatif aktivitas anak untuk menstimulus kemampuan motorik kasar anak. Agar permainan dapat berjalan dengan baik, perlu disesuaikan dengan tahapan perkembangan anak tunagrahita. Guru dan orangtua perlu memperhatikan aturan mainnya, harus dibuat lebih mudah dan singkat agar dapat dipahami anak usia dini tunagrahita. Guru dan orangtua juga harus menggunakan bahasa yang sederhana dan jelas serta perlu menyiapkan hadiah baik berupa pujian, tos ataupun sepotong biskuit (biskuit gandum). Diseminasi yang konsisten mengenai hasil penelitian ini dan hasil penelitian serupa diperlukan untuk mendukung perubahan di perilaku masyarakat dan sekolah.

\section{DAFTAR PUSTAKA}

Alfiza, Y., Martias, Z., Fatmawati. (2014). Meningkatkan keterampilan melompat melalui permainan tradisional lompat tali bagi anak tunagrahita ringan kelas II di SDLB 35 Painan. E-JUPEKhu, 3 (1), 299-307.

Ardiyanto, A \& Sukoco, P. (2014). Pengembangan Model Pembelajaran Berbasis Permainan Tradisional Untuk Meningkatkan Kemampuan
Motorik Kasar Anak Tunagrahita Ringan. Jurnal Keolahragaan, (2) 2. 119-129.

Asih L.S. (2014). Pengaruh Permainan Tradisional Engklek Terhadap Kemampuan Motorik Kasar Melompat Anak Tunagrahita Ringan (Single Subject Research (SSR). Pada Siswa SIb Bina Sejahtera ). Skripsi. Tidak diterbitkan. Bandung: PPS UPI Http://Repository.Upi. 
Edu/12357/1/S_Plb_1004924_Title.Pdf

Delphie, B. (2006). Pembelajaran anak tunagrahita. Bandung: Refika Aditama.

Fitriana S.S.E. (2013). Media pembelajaran interaktif ketrampilan membatik untuk anak tunagrahita ringan pada SLBN Semarang. Diakses dari Eprints.Dinus.Ac.Id/12475/1/Jurnal_12486. Pdf.

Luby, J. L. (2006). Handbook of preschool mental health. New York: The Guilford Press.

Odom, S. L., \& Wolery, M. (2003). A unified theory of practice in early intervention/early childhood special education: Evidence based practices. The Journal of Special Education. (37) 3, 164-173.

Ratoe Oedjoe, M \& Bunga, N.B. (2015). Model of East Nusa Tenggara traditional games as a learning mediafor young children with mental retardation. 6th International Conference on Teaching, Education and Learning (ICTEL) Singapore. Nov 15-16. 69-70.

Sari, S. (2015). Efektivitas permainan engklek untuk mengenal bilangan bagi anak tunagrahita sedang X DIII C1 SLB C Payakumbuh. E-JUPEKhu. (4) 1. 162-173. Diakses dari Http://Ejournal.Unp.Ac.Id/Index.Php/Jupekhu/ Article/Download/4632/3671.

Samuelsson, I.P \& Carlsson M.A., (2008). The playing learning child : Towards a pedagogy of early childhood, Scandinavian Journal of Education Research. (52) 6, 623-641. doi: $10.1080 / 00313830802497265$.

Sekarwati, D. A., \& Riyanto, E. (2015). Permainan maze matching board untuk mengembangkan kemampuan motorik halus anak tunagrahita. Artikel. Diambil dari www. ejournal.unesa. ac.id/article/6069/15/article.pdf

Permatasari F.D. (2014). Peningkatan kemampuan konsentrasi pada pembelajaran seni tari untuk anak tunagrahita di SLB Negeri 1 Sleman berbasis permainan tradisional. Skripsi. Tidak diterbitkan. Yogyakarta: UNY.

Utari, U.Y \& Indahwati, N. (2015). Upaya meningkatkan gerak dasar lokomotor anak tunagrahita ringan melalui permainan tradisional. Jurnal Pendidikan Olahraga dan Kesehatan. (03) 2 , 279 - 282. Diambil dari http://ejournal.unesa. ac.id/index.php/jurnal-pendidikan-jasmani/ issue/archive

Utari, Y. I \& Nanik I. (2015). Upaya meningkatkan gerak dasar lokomotor anak tunagrahita ringan melalui permainan tradisional. Jurnal Pendidikan Olahraga dan Kesehatan. (03) 02, 279-282. Diambil dari Http://Ejournal.Unesa. Ac.Id/Index.Php/Jurnal-Pendidikan-Jasmani/ Issue/Archive 